June - 2009

\title{
Sage without a Stage: Expanding the Object of Teaching in a Web-Based, High-School Classroom
}

\author{
Elizabeth Murphy and Maria A. Rodriguez-Manzanares \\ Memorial University of Newfoundland
}

\begin{abstract}
This paper reports on a study that uses cultural historical activity theory (CHAT) to make sense of e-teachers' activity in a context of high-school distance education. Data collection involved semistructured interviews with 13 e-teachers as well as seven management and support personnel in an organization responsible for the design and delivery of high-school distance education in the province of Newfoundland and Labrador, Canada. As well, the authors conducted a second round of interviews with 12 of the 13 teachers. Findings revealed that the traditional metaphor of teacher as 'sage on the stage' ceased to have a reference point in the distributed online classroom. The e-teachers were widening the object of their activity to include less teacher-centered forms of learning that involved more student independence.
\end{abstract}

Keywords: Online learning; e-teaching; high school; cultural historical activity theory; expansive learning.

\section{Introduction}

In reviews of research conducted in the 1980s and 1990s, Cradler and Bridgforth (1996) described technology as a "catalyst for education reform" (Preliminary Research Findings section, II 1). Technology has also been referred to as an agent of change (e.g., Furneaux, 2004; Girod \& Cavanaugh, 2001; Kiesler \& Sproull, 1987; McClintock, 1992). Guile (1998) argued that this change comes about because technology is not suited to practices where teachers operate as managers and didactic teachers. A similar argument was made earlier by Pea (1985) who explained that computers tend to be thought of as amplifying or extending our capabilities, but they can also play a role in changing what we do and how we do it by reorganizing our mental functioning. Besides being a catalyst for reform or a change agent, technology has been referred to as a Trojan horse. Salmon (1992) argued that computers fuel pedagogical change when they afford activities that require changes in the learning environment.

What these three metaphors have in common is their view of technology as an element that disrupts current practices. Christensen (see Bower \& Christensen, 1995; Christensen, 1997) first 
applied the term disruptive technology or disruptive innovation to the area of economics. In that context, disruptive technologies are described as "simple, convenient-to-use innovations that initially are used only by unsophisticated customers at the low end of markets" (Christensen \& Armstrong, 1998, p. 69). They constitute an alternative to established products or technologies dominating a field. They are perceived as being more responsive, agile, user-empowering, and potentially transformative.

Engeström's (2001) perspective on cultural historical activity theory (CHAT) and its principle of expansive learning provides a systematic and comprehensive tool to understand the transformative potential of disruptive technologies. Engeström argues that standard theories of learning "have little to offer" (p. 138) to our understanding of the processes involved in organizations where people "are all the time learning something that is not stable, not even defined or understood ahead of time" (p. 137). Engeström's argument focuses specifically on contexts where change is taking place or during "important transformations." At those times, as he notes, "we must learn new forms of activity which are not yet there. They are literally learned as they are being created. There is no competent teacher" (p. 138).

In this paper, we apply a lens of CHAT and its principle of expansive learning to make sense of a context where teachers are learning new forms of activity "which are not yet there." CHAT considers the cultural and historical dimensions of activity. With respect to the study of learning activity in particular, CHAT has been described as "one of many social approaches to learning" (Russell \& Yañez, 2003, p. 335). CHAT draws on Vygotsky's (1978) construct of cultural mediation of activity. Vygotsky represented cultural mediation as the mediation of a tool (artefact) between subject and object. CHAT broadened Vygotsky's triad of subject, object, and mediating artefact to include rules, community, division of labour, and outcome (see Engeström, 1987) in order to represent the activity system, which is defined as "object-oriented, collective, and culturally mediated human activity" (Engeström, 1999, p. 9). The object of activity is reinterpreted and "reconstructed in a wider perspective" (Virkkunen \& Kuutti, 2000, p. 303) when components of the activity system change substantially.

The e-teachers participating in our study were subjects in an activity system that had undergone considerable change. They had a history of practice of more than a decade in brick and mortar schools where physical co-presence formed the basis for interaction and communication. At the time of the study, they had all been working fewer than five years in an online, decentralized classroom where communication and interaction were mediated almost entirely by text and voice.

In this paper, we portray their new activity system and the contradictions that arise and lead to a change in the object of their activity of teaching. We begin with an overview of CHAT and its principle of expansive learning. We follow with a synthesis of studies that have used CHAT and its principle of expansive learning. Our findings are presented in relation to the elements of activity system and discussed using CHAT with a specific focus on expansive learning. 


\section{Cultural Historical Activity Theory and Expansive Learning}

The subject of an activity system is the individual or group whose viewpoint is adopted. Object "refers to the 'raw material' or 'problem space' at which the activity is directed and which is moulded or transformed into outcomes with the help of physical and symbolic, external and internal tools" (Engeström, 1993, p. 67). Tools (artefacts or instruments) mediate the object of activity. They can be external, material tools (e.g., a textbook, a computer) or internal, symbolic tools (e.g., language). Community refers to the participants of an activity system, who share the same object (Engeström, 1993). The division of labour involves the division of tasks and roles among members of the community and the divisions of power and status (Kuutti, 1996). Rules refer to explicit or implicit norms. Activity systems are typically represented as a triangle as follows:

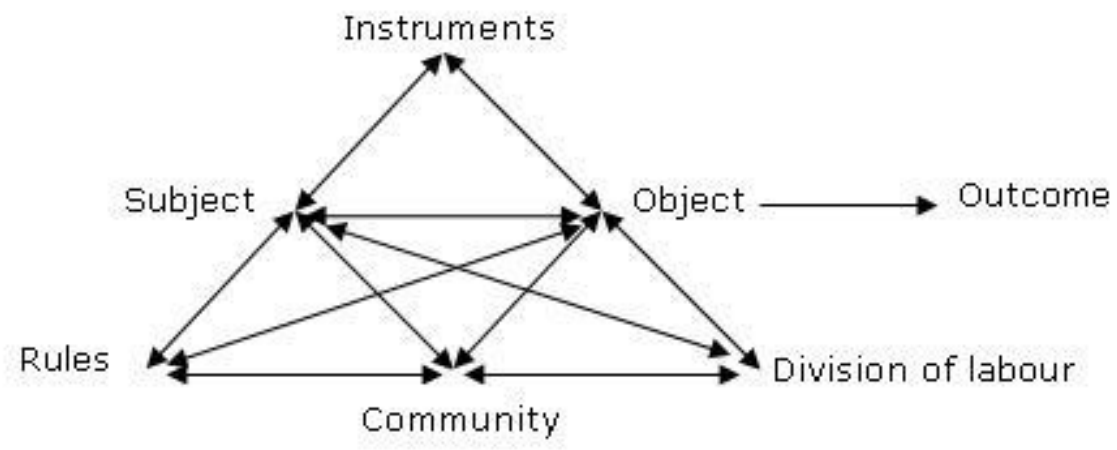

Figure 1. Activity theory diagram (Engeström, 1987).

According to the first of the five principles of CHAT as formulated by Engeström (2001), the main unit of analysis in CHAT is the activity system. An activity system is more robust than any of its individual members, as Engeström explains: "Goal-directed individual and group actions, as well as automatic operations, are relatively independent but subordinate units of analysis, eventually understandable only when interpreted against the background of entire activity systems" (p. 136). The second principle is the multivoicedness of activity systems, which can be both a source of trouble and of innovation. Multivoicedness refers to multiple perspectives, traditions, and interests.

As Engeström (2001) explains, "the division of labor in an activity creates different positions for the participants, the participants carry their own diverse histories, and the activity system itself carries multiple layers and strands of history engraved in its artifacts, rules and conventions" ( $p$. 136). The third principle is that of historicity. Engeström considers the history of activity systems as an essential step to understand their problems and potentials: "History itself needs to be studied as local history of the activity and its objects and as history of the theoretical ideas and tools that have shaped the activity" (pp. 136-137). Historical analysis is needed to understand an activity system in its present form because "parts of older phases of activities stay often embedded in them as they develop" (Kuutti, 1996, p. 26). 
The fourth principle highlights the central role of contradictions as sources of change and development. Contradictions are "historically accumulating structural tensions within and between activity systems" (Engeström, 2001, p. 137). They can create conflicts and disturbances but also attempts to transform the activity. A contradiction might occur, for example, when a new technology is adopted and then clashes with an old element such as the rules or division of labour.

The fifth principle refers to the possibility of expansive transformations in activity systems. An expansive transformation involves a reconceptualisation of the object and the motive of activity whereby "the practitioners ask what they are doing, and why, not just how they are doing it" (Engeström, 1991, p. 269). As Engeström (2001) notes, in a context of learning, such as learning within an organisation, the object of expansive learning activity is the entire activity system in which the learners are engaged, and expansive learning activity produces "new patterns of activity" (p. 139).

Virkkunen and Kuutti (2000) characterize expansive learning as a transformation in the object of activity. They draw on Engeström (1987) to argue that expansive learning occurs "when the object of the activity is reinterpreted, and the actors' interaction with the object is remediated to the effect that the object of the activity expands...." (p. 302). In activity systems, the object of activity is a key element, "the societal motive" (p. 301). The object "defines the activity and separates activities from each other" (p. 301). It is "a horizon of possibilities and possible objectives for the actors, something that unfolds in the process of the activity" (p. 301). Activity systems are multivoiced with "many competing and partly conflicting views" because, as Virkkunen and Kuutti note, "each individual taking part in a common activity has a slightly different view and interpretation of the object and purpose of the activity depending on the individual's position in the division of labor, his or her history in the activity, training and experience etc.” (p. 301).

The object of activity is reinterpreted and "reconstructed in a wider perspective" (Virkkunen \& Kuutti, 2000, p. 303) when components of the activity system change substantially and misalign, resulting in contradictions or double binds, which the individuals in the system overcome. Virkkunen and Kuutti provide this illustration:

For instance, new technology that has been adopted causes many disturbances and problems, but, it is impossible to return to the old technology.... Adopting new tools and practices creates contradictions between the old practices and the new ones. These contradictions are manifested in new kinds of problems, ruptures and disturbances in the activity. (p. 303)

It is in the resolution of the contradiction and a widened or expanded range of possibilities that learning and transformation occur in the form of a new object: "There is a constant tension between the expansive, future oriented solutions and the regressive ones that would mean return to the old practices. The solutions to the problems gradually give form to a new practice...." (Virkkunen \& Kuutti, 2000, p. 303). 


\section{Literature Review}

Kärkkäinen (1999) conducted a longitudinal study of teacher team planning and curriculum implementation in an elementary school setting in Finland. He identified disturbance clusters, together with questioning and interaction of different voices, as indicators of turning points. Disturbance clusters are clusters of dilemmas, disturbances, and innovation attempts of team discourse (Engeström, 1991). Kärkkäinen identified different types of turning points in object formation: widening the object in terms of spatiality, temporality and depth, narrowing the object, switching the object, and disintegration of the object.

The widening of the object in terms of depth took place when "the team elaborated on and created the concept of theme-working and also evaluated and reelaborated on the concept so that the ideological dimension of the object became deeper" (Kärkkäinen, 1999, p. 191). The author also argued that the tension between controlling students' choices and offering choice resulted in the team's elaboration of a new pedagogy emphasizing the facilitation of students' learning. Spatial widening involved the teachers' attempts to expand teacher collaboration.

Engeström, Engeström, and Suntio (2002a, 2202b) investigated middle school teachers' integration of technology in a Finnish school and the teachers' ways of constructing or defining their students. Analysis of data revealed a contradiction related to "teachers' repeated talk about students as apathetic," which contrasted with "occasional utterances where they would contradict their very assessment" (Engeström et al., 2002a, p. 215). Teachers changed this conceptualization of students as "apathetic" moving to one of students as "capable." The authors identified expansive actions on the part of teachers related to this redefinition of students. An instance in which teachers sought input from students before a unit was implemented was interpreted as an illustration of expansive action which was "atypical to the everyday instructional practice in the school” (Engeström et al., 2002b, p. 323).

Carr, Morrison, Cox, and Deacon (2007) investigated wikis as mediating artefacts in a final-year undergraduate political science course which was taught face-to-face. The study revealed that the collective process of creating and using wikis challenged well-established teacher-centered instruction and resulted in "uncertainties and anxieties for both educators and students" (p. 271). The authors highlighted the "multiple mediations" characteristic of wikis, whereby "web pages can... not only be read but also be easily edited and extended by multiple participants through a browser" (p. 268). Students' use of wikis involved a shift from "just-in-time individual projects" (p. 278) to collaborative writing. For the tutors and lecturer in the study, this shift meant developing practices to help students with collaborative writing in wikis.

In a context of teacher education at the University of Hong Kong involving partnering of university tutors, mentor teachers, and student teachers, Tsui and Law (2007) identified a shift in the conceptualization of teacher learning. One contradiction between the subjects and the division of labour stemmed from the fact that "while lessons are collectively prepared, they are individually enacted by teachers in the classroom" (p. 1298). 
The experienced university tutors and mentor teachers brought their multiple perspectives to the collective lesson planning in which they considered student teachers "partners;" however, student teachers "were completely overwhelmed by the input... [and] did not have enough time and space to make sense of the input and to gain ownership of the ideas" (Tsui \& Law, 2007, p. 1298). Subsequently, participants agreed to change lesson planning so that student teachers could prepare on their own, with university tutors and mentor teachers adopting a consultative role. Tsui and Law interpreted this shift as expansive learning where the new concept of lesson planning constituted a "new mediating tool for learning... [which] led to a transformation of the activity system from the 'supervision' of novices to the professional development of both novices and experts” (p. 1300).

In Australia, Fåhræus (2004) collected data from 40 distance education students, most of whom were at the secondary level, as well as teachers and others who were part of the students' learning activity. The main contradiction in the study related to a tradition of individual learning in distance education where students do not interact with each other. This lack of interaction clashed with the affordances of the new tools that enabled collaboration in the online leaning environment. It clashed as well with learners' preference for collaborating during online classes. Fåhræus suggested that potential activities to resolve that contradiction might involve a redefinition of roles and rules as well as changes in pedagogy to adapt to collaborative views of learning.

Russell and Schneiderheinze (Russell, 2004; Russell \& Schneiderheinze, 2005) reported on a study of four teachers designing a problem-based unit delivered using technology in fourth- and fifth- grade classrooms in four different schools in Missouri. Each teacher's work activity was analysed using the elements of the activity system. Analysis focused on indications of object transformation or "ways in which the teacher delineated the object in a new way" (Russell \& Schneiderheinze, 2005, p. 40). Contradictions could be resolved when "the teacher was able to maintain or expand her object by working out the tensions in the system" (Russell, 2004, Method section, ๆ 7). They could be unresolved when "the teacher did not work out the tensions and the object was narrowed" (Method section, ๆ 7).

\section{Methods}

\section{The Context}

The context for our study was distance education at the high-school level in the province of Newfoundland and Labrador, Canada, where approximately 65 percent, or 184 out of a total of 285 schools, are classified as rural. The Centre for Distance Learning and Innovation (CDLI) was created in the year 2000 to provide web-based high-school education to these populations. At the time of our study, 30 courses were offered to high-school students in approximately 100 schools, with 1,500 enrolments and 27.5 e-teachers (see Government of Newfoundland and Labrador, 2006, 2007). Students attend physical schools and supplement their course offerings with distance courses delivered by CDLI. 
E-teachers teach courses from multiple locations across the province, such as offices within schools, within the university, or within other centers, through both synchronous and asynchronous classes (CDLI, 2007). Some of the e-teachers are also involved in course development (Barbour, 2007). Asynchronous instruction was supported by the learning management system WebCT ${ }^{\mathrm{TM}}$. Synchronous classes relied on Elluminate Live ${ }^{\mathrm{TM}}$ (E-Live), which includes features such as voice-based communication, direct messaging, a whiteboard, polling, breakout rooms, application sharing, and a graphing calculator. E-Live supported twoway audio when the study was conducted. Videoconferencing was not used extensively at that time due to bandwidth requirements.

\section{Participants and Data Collection}

Volunteer participants were recruited among teachers and other management and support staff working for the organisation. Recruitment involved obtaining permission from the organisation to contact potential participants, who received information about the study in writing as well as a consent form. All participants who returned signed consent forms were included in the study.

The first phase of data collection took the form of 90-120 minute semi-structured interviews (Patton, 1990). Interviews were primarily conducted using E-Live, the voice-based collaborative tool that CDLI e-teachers use for synchronous classes. The first set of interviews was conducted with 13 e-teachers representing a range of subject areas. In order to gain additional insights into the organization, we also interviewed seven individuals such as managers and support personnel who were part of the teachers' activity system. Questions were grouped into categories and related to teachers' personal histories, teaching approaches, tools, challenges, and constraints.

In the second phase of data collection, 12 of the 13 e-teachers interviewed in the first phase were interviewed once again. This second set of interviews focused more specifically on e-teaching. Participating e-teachers were encouraged to use E-Live to display e-teaching resources. Questions

for this second set of interviews were designed to consider how teachers make use of the tools to engage and interact with students.

\section{Data Analysis}

Interviews were recorded and archived in E-Live and subsequently transcribed. The transcriptions from both sets of interviews were gathered into one file. Instead of using the sentence or paragraph as a reference point for analysis, we broke the interview transcripts into statements "which convey one identifiable idea" (Aviv, 2001, p. 59). Statements were then associated with elements of the activity system. For example, all statements pertaining to the e-teacher, him or herself, were grouped under 'subject'. Statements pertaining to norms or established ways of proceeding were grouped under 'rules.' Likewise statements were grouped under headings of 'community,' 'division of labour,' 'tools,' and 'object.' Like statements were synthesized. Findings are reported under these headings and use, as much as possible, the actual words of the e-teachers. 


\section{Findings}

\section{Subjects}

All e-teachers in the study had a minimum of 11 years of experience teaching in the face-to-face (F2F) classroom before coming to teach in an online classroom. They had not received formal education or training related to teaching online beyond in-service activities offered within CDLI, learning on the job, and sharing between e-teachers.

Recruitment policies of CDLI require that those hired be innovative, experienced, established, risk-taking, inquisitive, open to dialogue, self-aware, aware of others as well as willing to experiment, to collaborate, and to reach out to colleagues. It is expected that they show "due diligence" and "attention to detail and individual needs." In addition, hiring practices favour those who have a cooperative spirit, who put students first, who are "givers and not takers" and who "have succeeded well in the $[\mathrm{F} 2 \mathrm{~F}]$ classroom."

\section{Object}

All e-teachers had attended F2F schools as learners themselves and had participated in teachereducation programs in F2F learning environments where, as one individual noted, you learned that "you were the source" and "students are there to be taught." One e-teacher noted that if he went back to the classroom his F2F teaching would be enhanced by what he learned online in terms of "the techniques of engaging students." One e-teacher described how her teaching had evolved:

I've become more a facilitator. I don't teach [students] anymore... They take control of what they do... I provide the tools... In the first year or two that I taught, I taught like I would in a face-to-face classroom, a lecture, [but] I've adapted my role as a teacher... When I moved to teaching online, I still retained a percentage of the old 'sage on the stage' model of teaching. That is changing.

In terms of the future vision and potential for the activity of the e-teacher in the organisation, one manager referred to his desire for use of the Internet to create "multiple pathways" to knowledge and establish a democratic power structure where "power shifts from the organization, the institution, to the learner." The organisation was moving towards an "activity-centered" approach to online teaching. One individual commented regarding online teaching as follows:

We have got a vision of what good teaching looks like. I think there is more consistency in that image than there is inconsistency.... We are all there trying to work towards what we think good learning is at this point in time. We are going to change like we've always changed. 
Moving to the new online environment meant that "no one had a road map to follow, nobody had firmly established their routine" because "people were in such a new area." The newness created an opportunity to establish new forms of practice, as illustrated by the comment from one manager: "I usually create this expectation, this sense of tension, well in advance; we are on the road towards moving to a more student-centered approach to education.... Here's the roadmap and we expect [e-teachers] to get on it." The lack of spontaneity afforded by the technologicallymediated classroom meant that e-teachers had to become more intentional, deliberate, more organised, better listeners, and more aware of gauging student understanding.

\section{Community}

When e-teachers taught in F2F contexts, they could get to know students personally and outside of the classroom through, for example, participating in extra-curricular activities, such as coaching sports' teams. In most cases, they lived and worked in the same community as their students. This meant that they were also able to have easy contact with them outside of school. Students already knew who their teachers were, where they came from, what kind of person they were to work with on a day-to-day basis, and what they were involved in around the school.

As e-teachers, they were teaching students from a variety of communities within the province. Contact had to be deliberate and planned. The limitations of bandwidth meant that videoconferencing was not always a preferred option for communicating. Given that students might be dispersed across two provinces, two time zones, and up to 100 communities, F2F visits were an exception. Creating community online "requires a conscious effort," unlike in the F2F context, where it can occur naturally because of physical co-presence. Additionally, online students can be "distributed,... one in every community," which means that they come with different learning styles or academic levels, as in F2F classrooms, but also with different school cultures and community differences regarding the value attached to education.

\section{Rules}

Teaching in the F2F environment could be informal, spontaneous, and "on the fly." As one person noted, "in a face-to-face classroom, in the two minutes it takes for kids to find their seats I can assess the homework." Teachers could also make up the time next day if they hadn't covered all the content in one class. They could easily just physically move students to one part of the room for small group discussion.

In the online environment, scheduling difficulties and glitches were common because not all schools had adapted their schedules to those of the online courses. In some cases, e-teachers were required to juggle class schedules that overlap in Newfoundland versus Labrador's time zone. Teachers might sometimes "revert back to... a lecture-type based hour" in order to cover curriculum in the six out of 10 periods of synchronous classes.

In the F2F classroom, instruction was confined to a typical 9:00 to 3:00 day when teachers and students were physically co-present. In the online classroom, access to online communication 
tools meant that interaction with students was no longer confined to the school day but could be potentially "24/7." Teaching was no longer defined by co-presence because students were expected to work independently for approximately $40 \%$ of the time. Monitoring students in the four out of 10 periods of asynchronous classes might be difficult, especially if students did not have the skills to work independently.

\section{Tools}

In the F2F classroom, students could get to know teachers visually when they walked into the classroom because of the information conveyed by physical presence. It was possible to monitor students' work and discern whether students were understanding or paying attention simply by walking down the aisles, by "the look on their faces" or by "that glazed-over look." As one individual noted, in the F2F classroom, "you can pretty easily read the body language of a student who is unfocused and quickly get them back on track." Communication was made easier by reliance on "visual cues in posture and facial expression." In the online classroom, the lack of physical co-presence as a mediating tool made it more difficult to spontaneously interact with students because, as one individual commented, “you don't get to see the reactions, you don't get to see the frowns or smiles, you don't get to take visual cues from your environment... you are not getting the body language."

E-Live can be used for a "lecture-mode" style of teaching to the point that one e-teacher described having to "monitor" himself when using it. According to one manager, E-Live "does not really celebrate that democratic function [of] the internet..., the luxury of exploration." Although connectivity had improved, there were still technological difficulties related to bandwidth limitations. In addition, it might be difficult to "draw students out" during synchronous lessons because they preferred text-based messaging as opposed to voice communication, or they might be shy, "hibernate," or "want to be invisible."

E-teachers could overcome the disadvantages in the technology and counter its limitations, as one individual highlighted: "The tools are what they are. I don't see them as being constraining. I think we just have to make best use of them." Some e-teachers referred to taking advantage of the private communication feature of instant messaging for one-on-one support outside of class or for feedback in synchronous classes, as one individual explained:

We're not getting feedback, the facial expressions; you're not reading the signals from the students that indicate lack of comprehension or boredom. But at the same time we can get instant feedback, so you have to use the technology to counter that limitation.

Some voices in the system argued that effective use of the tools could allow e-teachers to know students better online than in the F2F classroom: "I can't recall having some of the contact with students in the regular classroom that I have now that I'm online." 


\section{Division of Labour}

Historically, teachers could often perceive students' problems by talking to them in the corridors during "off-chance" casual conversations or by going down the hall and meeting with the principal. They could know from the principal about an issue with a student and the principal would address the issue with the teachers. Because all CDLI students are enrolled in physical schools, their e-teachers must deal with different schools for administration and invigilation of examinations, technical support, and reporting periods. Students might be absent from class yet the e-teacher might not know in advance whether the reason is sickness, a school event, holiday, or a closure due to weather. E-teachers might "find out after that fact that... a student has gone through a difficult time."

The "immediacy" of communication and "reduction of bureaucracy" in the organization were "unlike the face-to-face world of school districts." As one e-teacher explained, he "felt much more isolation" when he taught F2F. Unlike in the F2F classroom, online "there are no walls or doors, and... as a result, sharing is something that happens naturally." One individual described the organization as "very supportive environment and very helpful." Specific examples of support include attention to ergonomic needs, additional preparation time beyond what would be provided to other teachers within the province in F2F classrooms, mentoring, and professional development. The system's division of labour also creates opportunities for e-teachers' input to be considered, as one manager described:

It's easier with a small group of people ... [whereas] in a regular face-to-face environment, to actually be able to do that, you would have to go to the school and the school board and so on and so forth... It's easier for an e-teacher... to effect change with us.

In Figure 2 below, we provide a graphic summary of the elements of the activity system of the eteachers in our study. 


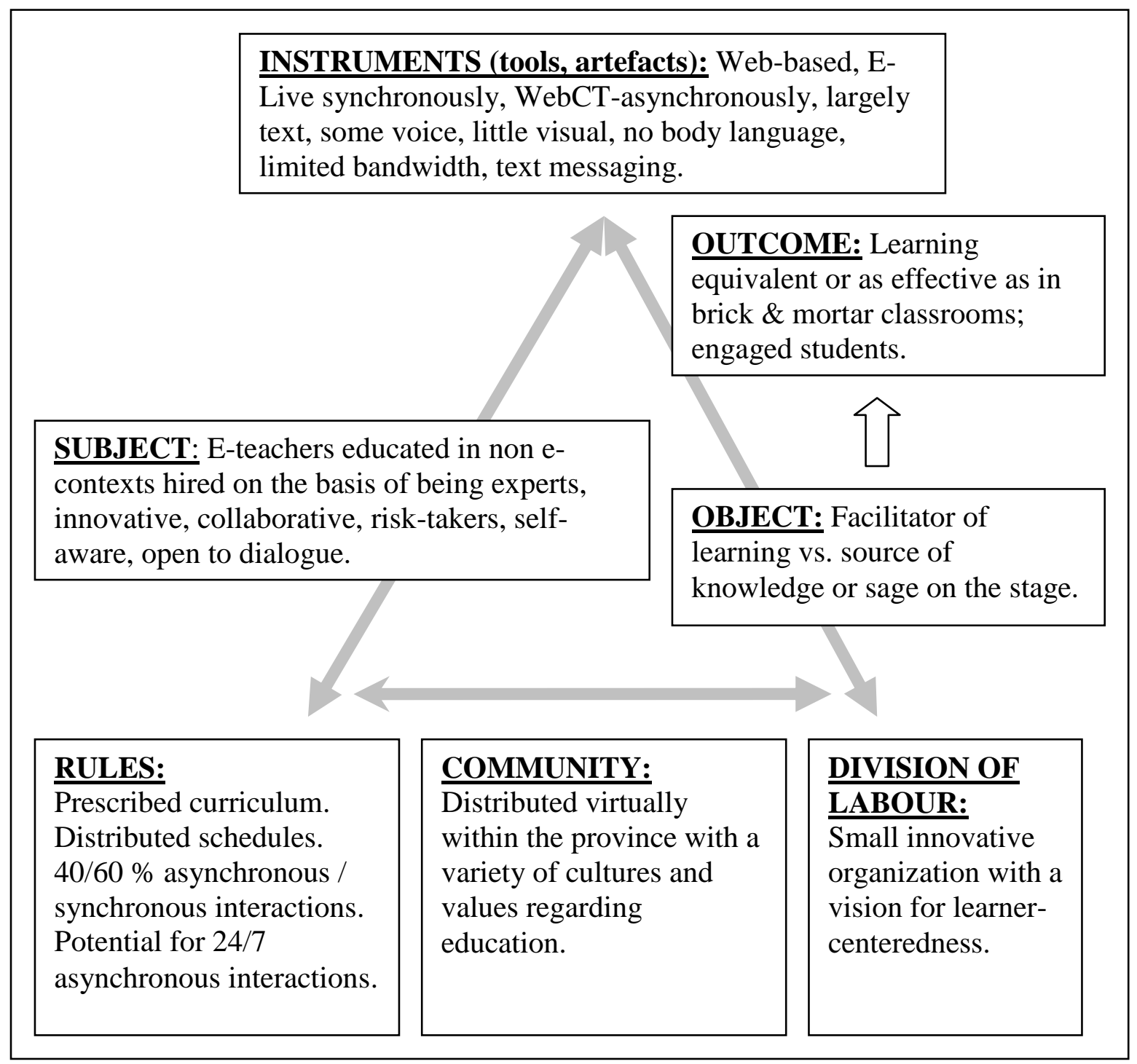

Figure 2. Activity system of e-teachers in study.

\section{Discussion}

The e-teachers were practicing in the online classroom but their reference points for teaching were, for the most part, based on brick and mortar F2F classrooms. Their history of teaching, their own experiences as learners, as well as their pre-service education program have not prepared them for the changes brought about by web-based learning. They are in a position where they must, as Engeström (2001) explains, "learn new forms of activity which are not yet there" (p. 138).

As Virkkunen and Kuutti (2000) explain, the object of activity is reinterpreted and "reconstructed in a wider perspective" (p. 303) when components of the activity system change substantially. Many aspects of the activity system of the e-teachers in our study had undergone substantial change. The community was distributed rather than centralized. In terms of rules, teaching and 
learning had become almost as much an asynchronous as a synchronous activity. In relation to the division of labour, the teacher was part of not a school but an innovative organization dedicated to online learning. The symbolic tools of body language were replaced in this system by text and some voice interactions.

Community as place, familiar faces, spontaneous interactions, and automatic social presence was not what the online classroom offered. Community in the online classroom was something in the process of being defined and that was slowly emerging as a new form of activity. Rules dictating that a student be in class with a teacher during the school day were replaced with periods of independent work. Working in a technologically mediated environment called for new norms, new strategies, and new ways of behaving. All interactions from checking homework to communicating required more deliberate, intentional, and planned approaches.

In terms of the division of labour, there was a lack of spontaneity in the online classroom, which meant that e-teachers could not interact informally with students nor could they walk down the hall to make enquiries at the principal's office about a particular student. Identifying problems in students was a part of the teacher's practice but online it could not be done in the same way as the teachers had done it historically.

It was the change in tools that caused the most disruption in the e-teacher's activity system. The behaviours and repertoire of strategies teachers might have relied on as practitioners in F2F contexts did not always make sense when interaction and communication were mediated by a different set of tools. The traditional reliance on symbolic mediating tools of body language and visual cues was no longer possible in their online classrooms.

The contradictions between, on one hand, how teachers had historically learned to practice and, on the other, the fact that the online classroom didn't support those ways of practicing required the e-teachers to adopt new approaches, new beliefs, and new ways of thinking about teaching. Some voices were nostalgic about the loss of the F2F classroom while others were focused on adapting to the new classroom and on seeing its possibilities. Some voices had resolved the contradictions between how they had traditionally conceptualized and practiced teaching and how it needed to be practiced and conceptualized for the online classroom. Moving towards more independent, facilitative, and engaged forms of learning represented a means of resolving many of the contradictions faced in the activity system.

Engeström (2001) refers to an expansive learning trigger as "conflictual questioning of the existing standard practice" (p. 151). The existing standard practice in the case of the e-teachers would be the teacher-centred classroom, characterized by what one e-teacher described as the "sage on the stage" model of teaching, with teacher as "source." The metaphors of sage on the stage and source ceased to have a reference point because in the distributed online classroom there was no longer a stage or a single, central source. The object of the activity of the e-teachers had become widened to involve more independent and engaged forms of learning. 


\section{Conclusions, Implications, and Limitations}

The metaphors of technology as a catalyst, an agent of change, or a Trojan horse focus attention on the fact that technology brings about changes in teaching and learning. In our study, the use of CHAT provides a comprehensive and complex illustration of how teachers were required to learn new forms of activity in order to effectively teach in an online classroom. The new forms of activity required that the e-teachers question many of the behaviours practiced historically and that they adopt more learner-centered forms of practice.

As our literature review illustrated, others have used a CHAT framework to understand expansive learning. Unlike those studies, in our context the introduction of web-based learning necessitated substantial changes in all aspects of the activity system. The changes of the object described in the studies reported on in our review focused typically on one aspect of teaching and learning, for example on teacher team work (Kärkkäinen, 1999), conceptualization of students (Engeström et al., 2002a, 2202b), developing practices to help students with collaborative writing (Carr et al., 2007), professional development of both novices and experts (Tsui \& Law, 2007), and collaborative forms of learning (Fåhræus, 2004).

Our study was also different from other studies of K-12 distance learning (e.g., Rice, Dawley, Gasell, \& Florez, 2008) in that adopting a CHAT perspective allowed us to move beyond identifying needs or difficulties in order to focus on changes in teachers' practices. The context of our study was an ideal vantage point for understanding how teachers might change their practice to move towards more learner-centred, facilitative forms of teaching. These forms are clearly identified in the literature, for example in learner-centeredness frameworks (e.g., APA Work Group of the Board of Educational Affairs, 1997) and the educational literature on constructivism (e.g., Duffy \& Cunningham, 1996; Savery \& Duffy, 1996, Wells \& Chang-Wells, 1992), as being ideals to which teachers and schools should aim.

In terms of implications, the e-teachers in our study may need more opportunities to reconcile the past and present forms of their practice. This reconciliation might be accomplished through professional development experiences that focus reflection on the differences between what is possible or not possible in an online versus a F2F classroom. They may also need opportunities to envisage and realise the potential of the tools to help them meet their goals and to support learnercentered approaches. Ongoing dialogue and open and frequent communication within the organisation may help communicate the road map more explicitly. In general, the findings suggest that the pre-service education programs from which the e-teachers graduated may not be preparing them for online teaching.

Our study was limited to only one context of high-school distance education, in one province of Canada, with one group of e-teachers. Future studies of distance education contexts might take the perspective of students or parents. We did not use data sources besides interviews, such as observations or document analysis. It is possible that use of other sources may have provided different insights from those reported on in this paper. 


\section{Acknowledgements}

This study was made possible by a grant from the Social Sciences and Humanities Research Council of Canada (SSHRC) and by in-kind support from the Centre for Distance Learning and Innovation, Government of Newfoundland and Labrador, Canada. Thank you to research assistants Bruce Nolan and Janine Murphy and to the two blind reviewers of an earlier version of this paper who added invaluable insights and modifications. 


\section{References}

APA Work Group of the Board of Educational Affairs (1997). Learner-centered psychological principles: A framework for school reform and redesign. Washington, DC: American Psychological Association. Retrieved February 4, 2009, from http://www.apa.org/ed/cpse/LCPP.pdf

Aviv, R. (2001). Educational performance of ALN via content analysis. Journal of Asynchronous Learning Networks, 4(2), 53-72. Retrieved August 13, 2008, from http://www.aln.org/publications/jaln/v4n2/pdf/v4n2_aviv.pdf

Barbour, M. K. (2007). Principles of effective web-based content for secondary school students: Teacher and developer perceptions. The Journal of Distance Education, 21(3), 93-114.

Bower, J. L., \& Christensen, C. M. (1995). Disruptive technologies: Catching the wave. Harvard Business Review, 73(1), 43-53.

Carr, T., Morrison, A., Cox, G., \& Deacon, A. (2007). Weathering wikis: Net-based learning meets political science in a South African university. Computers and Composition, 24(3), 266-284.

Centre for Distance Learning and Innovation (CDLI) (2007). CDLI, The Centre for Distance Learning and Innovation. Retrieved September 21, 2007, from http://www.cdli.ca/index.php

Christensen, C. M. (1997). The innovator's dilemma. Cambridge, MA: Harvard Business School Press.

Christensen, C. M., \& Armstrong, E. G. (1998). Disruptive technologies: A credible threat to leading programs in continuing medical education? Journal of Continuing Education in the Health Professions, 18(2), 69-80.

Cradler, J., \& Bridgforth, E. (1996). Technology as a catalyst for education reform. San Francisco, CA: Far West Laboratory for the California Department of Education. Retrieved September 25, 2007, from http://www.wested.org/techpolicy/techreform.html/

Duffy, T., \& Cunningham, D. (1996). Constructivism: Implications for the design and delivery of instruction. In D. H. Jonassen, (Ed.), Handbook of research for educational communications and technology (pp. 170-198). New York: Simon and Schuster.

Engeström, Y. (1987). Learning by expanding: An activity-theoretical approach to developmental research. Helsinki: Orienta-Konsultit. Retrieved July 19, 2007, from http://communication.ucsd.edu/MCA/Paper/Engestrom/expanding/toc.htm 
Engeström, Y. (1991). Developmental work research: Reconstructing expertise through expansive learning. In M. I. Nurminen \& G. R. S. Weir (Eds.), Human jobs and computer interfaces (p. 265-290). Amsterdam: Elsevier Science Publishers.

Engeström, Y. (1993). Developmental studies of work as a testbench of activity theory: The case of primary care medical practice. In S. Chaiklin \& J. Lave (Eds.), Understanding practice: Perspectives on activity and context (pp. 64-103).New York, NY: Cambridge University Press.

Engeström, Y. (1999). Activity theory and individual and social transformation. In Y. Engeström, R. Miettinen, \& R. Punamaki (Eds.), Perspectives on activity theory (pp. 19-38). New York: Cambridge University Press.

Engeström, Y. (2001). Expansive learning at work: Toward an activity theoretical reconceptualization. Journal of Education and Work, 14(1), 133-156.

Engeström, Y., Engeström, R., \& Suntio, A. (2002a). Can a school community learn to master its own future? An activity theoretical study of expansive learning among middle school teachers. In G. Wells \& G. Claxton (Eds.), Learning for life in the 21st century: Sociocultural perspectives on the future of education (pp. 211-224). Cambridge, MA: Blackwell.

Engeström, Y., Engeström, R., \& Suntio, A. (2002b). From paralyzing myths to expansive action: Building computer-supported knowledge into the curriculum from below. In G. Stahl (Ed.), Computer support for collaborative learning: Foundations for a CSCL community (pp. 318-324). Hillsdale, NJ: Lawrence Erlbaum.

Fåhræus, E. R. (2004). Distance education students moving towards collaborative learning: A field study of Australian distance education students and systems. Educational Technology \& Society, 7(2), 129-140.

Furneaux, C. (2004, May). How does information technology impact the methods, potential and purpose of education? Paper presented at the Effective Teaching and Learning Conference, Griffith University, Brisbane. Retrieved July 20, 2008, from http://eprints.qut.edu.au/archive/00000794/01/Craig_Furneaux_-

_Information_Technology.pdf

Guile, D. (1998). Information and communication technology and education. London: Institute of Education, University of London.

Government of Newfoundland and Labrador (2006). Education statistics: Elementarysecondary, 2005-2006. Retrieved November 22, 2006, from http://www.ed.gov.nl.ca/edu/pub/stats05 06/stats05 06.htm 
Government of Newfoundland and Labrador (2007). Department of Education annual report 2005-2006. Retrieved May 22, 2007, from http://www.ed.gov.nl.ca/edu/pub/ann_rep/doe_ar05-06.pdf

Kärkkäinen, M. (1999). Teams as breakers of traditional work practices: A longitudinal study of planning and implementing curriculum units in elementary school teacher teams. Doctoral dissertation, University of Helsinki, Finland. Retrieved January 11, 2007, from http://ethesis.helsinki.fi/julkaisut/kas/kasva/vk/karkkainen/teamsasb.pdf

Kiesler, S., \& Sproull, L. (1987). Computing and change on campus. New York: Cambridge University Press.

Kuutti, K. (1996). Activity theory as a potential framework for human-computer interaction research. In B. A. Nardi (Ed.), Context and consciousness: Activity theory and humancomputer interaction (pp. 17-44). Cambridge, MA: MIT Press.

McClintock, R. (1992). Power and pedagogy: Transforming education through information $\begin{array}{lllll}\text { technology. } & \text { Retrieved } & \text { February } & \text { 2009, from }\end{array}$ http://www.ilt.columbia.edu/publications/mcclintock.html

Patton, M. (1990). Qualitative evaluation and research methods (2nd ed.). Thousand Oaks, CA: Sage.

Pea, R. D. (1985). Beyond amplification: Using the computer to reorganize mental functioning. Educational Psychologist, 20(4), 167-182.

Rice, K., Dawley, L., Gasell, C., \& Florez, C. (2008). Going virtual! Identifying the unique needs and challenges of K-12 online teachers. Washington, D.C.: North American Council for Online Learning. Retrieved February 20, 2009, from http://edtech.boisestate.edu/goingvirtual/goingvirtual2.pdf

Russell, D. (2004). Paradigm shift: A case study of innovation in an educational setting. International Journal of Instructional Technology and Distance Learning, 1(12). Retrieved January 29, 2009, from http://www.itdl.org/Journal/Dec_04/article03.htm

Russell, D. L., \& Schneiderheinze, A. (2005). Understanding innovation in education using activity theory. Educational Technology \& Society, 8(1), 38-53.

Russell, D. L., \& Yañez, A. (2003). 'Big picture people rarely become historians': Genre systems and the contradictions of general education. In C. Bazerman \& D. R. Russell (Eds.), Writing selves/writing society: Research from activity perspectives (pp. 331-362). Fort Collins, CO: WAC Clearinghouse. Retrieved January 30, 2009, from http://wac.colostate.edu/books/selves societies/selves societies.pdf 
Salmon, G. (1992). Effects with and of computers and the study of computer-based learning environments. In E. De Corte, M. Linn, H. Mandl, \& L. Verschaffel (Eds.), Computerbased learning environments and problem-solving (pp. 247-262). Berlin: SpringerVerlag.

Savery, J., \& Duffy, T. (1996). Problem based learning: An instructional model and its constructivist framework. In B. Wilson (Ed.), Constructivist learning environments: Case studies in instructional design (pp. 135-148). Englewood Cliffs, NJ: Educational Technology Publications.

Tsui, A. B. M., \& Law, D.Y. K. (2007). Learning as boundary-crossing in school university partnership. Teaching and Teacher Education, 23(8), 1289-1301.

Virkkunen, J., \& Kuutti, K. (2000). Understanding organizational learning by focusing on "activity systems." Accounting, Management and Information Technologies, 10, 291319.

Wells, G., \& Chang-Wells, G. L. (1992). Constructing knowledge together: Classrooms as centers of inquiry and literacy. Portsmouth, $\mathrm{NH}$ : Heinemann.

Vygotsky, L. (1978). Mind in society: The development of higher psychological processes. Cambridge, MA: Harvard University Press.

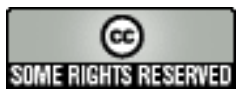

